\title{
Influence of an Individual Health - Improving Training Program on the Physical and Functional Preparedness of Students
}

Svetlana Otaraly ${ }^{1}$, Alya Zhumanova ${ }^{2}$, Aibek Alikey ${ }^{3}$, Zhanna Sabyrbek ${ }^{4}$, Nataliya Shepetiuk ${ }^{5}$, Sniegina Poteliūniené ${ }^{6}$

\footnotetext{
$1 \quad$ Al-Farabi Kazakh National University, 71 Al-Farabi av., KZ-050040, Almaty, Kazakhstan, otaraly17@mail.ru Kazakh Academy of Sport and Tourism, 85 Abay av., KZ-050022, Almaty, Kazakhstan, otaraly17@mail.ru Kazakh Academy of Sport and Tourism, 85 Abay av., KZ-050022, Almaty, Kazakhstan, ALIS005@mail.ru Al-Farabi Kazakh National University, 71Al-Farabi av., KZ-050040, Almaty, Kazakhstan, aaibek-82@mail.ru L.N.Gumilyov Eurasian National University, 2 Satbayev St., KZ-010000 Nur-Sultan, Kazakhstan, aaibek-82@mail.ru Al-Farabi Kazakh National University, 71Al-Farabi av., KZ-050040 Almaty, Kazakhstan, s.zhanna@mail.ru Al-Farabi Kazakh National University, 71 Al-Farabi av., KZ-050040 Almaty, Kazakhstan,nshepetyuk82@mail.ru Vytautas Magnus University, Academy of Education, T. Ševčenkos g. 31, LT-03111, Vilnius, Lithuania, sniegina.poteliuniene@vdu.lt
}

\begin{abstract}
The purpose of this study is to investigate the influence of an individual health-improving training program on the physical and functional fitness of 1st-year students. The results of the study confirm the positive impact of an individual health-improving training program on the physical and functional fitness of students. Analysis of obtained data proves the need to further larger-scale research in the field of incorporating individual health-improving training programs into the educational process of physical education.
\end{abstract}

Keywords: students, adaptation, physical education, functional fitness.

\section{Introduction}

The socio-economic transformations of the last decades have led to a number of adverse changes in the physical status, psychological state, and health of students. One of the reasons for this is the low level of physical activity, which can lead to adverse consequences in a short and long term. In this regard, the priority activity of teachers in 
physical education is the search for effective means and methods of physical education in order to improve students' health, motivation for physical exercises, and develop concepts of healthy lifestyle formation during the period of study at university.

\section{Background}

The period of study at university, according to Norkus (2012), Barnett, Clark, Linkletter, Loxley, Rogers and Ott (2013), is an important and critical period in the lives of young people. In their opinion, habits formed during the period of study at university effects on behavior and lifestyle of students, which they will adhere to in the future. Lifestyle changes, lack of free time, the need to adapt to new living and material conditions, building new relationships in the educational environment, information overload, these are, all the factors that characterize educational activities today, are the causes of stress, depression, psycho-vegetative disorders (Graf \& Welle, 2014; Molodcov \& Kamaev, 2001; Shagina, 2010). This, in turn, negatively effects on attitude of students to their health (Kiseleva, 2010; Meermanova, Kojgel 'dinova \& Ibraev, 2017) and forms habits of drinking alcohol, neglecting rational nutrition, and decreasing students' physical activity (El Ansari et al., 2011). Formed negative trends in relation to students' health can have great consequences in future for both the individual and the country's economy (Eichorn, Brune, Short \& Abraham, 2018; Sylvia, Bernstein \& Hubbard, 2014). Even today, more and more authors indicate a decrease in level of physical development, functional and physical fitness of students, deterioration of health, and increase in the number of students suffering from various kinds of chronic diseases from year to year in their studies (Batrymbetova, 2008; Pavlova, Kotova, Kislyakova, Sarajkin \& Kamskova, 2016); Poteliūniene, 2010). The main reason for the decline in the physical status of most students is a low level of physical activity (Ivashchenko, Yermakova, Cieslicka \& Muszkieta (2015); Lipošek, Planinšec, Leskošek \& Pajtler, 2018; Pylypei, 2013; Vlahii \& Yachniuk, 2015).

In this regard, it is necessary to take a set of measures to prevent the consequences of all these adverse events. The sociocultural context is important to solve this problem since the physical activity of students varies from country to country (Haase, Steptoe, Sallis \& Wardle, 2004), and the physical education of students is organized and promoted in different ways.

In many European countries, compulsory physical education in higher educational establishments was cancelled, and currently, a search of ways for creating favorable conditions for students to study after lectures is carried out. In countries where physical education remains as a compulsory discipline, the transformation of physical education curricula is ongoing and new educational technologies are being sought to help improve students' health and promote physical self-development. In these conditions, the importance of "Physical education" discipline increases as means of satisfying students" 
needs for physical activity, teaching conscious, purposeful planning of physical activity, improving their physical and functional state, and forming mindset on a healthy lifestyle. Zhigareva (2016) believes that the formation of students' understanding that health is the highest value, and maintaining it throughout life is impossible without formation of habits for the conscious use of physical exercises is the main goal of this discipline. However, according to Kuzmina, Lebedinskij and Shvachun (2020), the traditional forms of organization of students' motor activity and the formed vector of interaction between teachers and students not only does not solve the tasks set for physical education, but also lead to a decrease in the need for systematic physical exercises and negative attitude of students to "Physical education" discipline.

Therefore, the priority area of activity of specialists in the field of physical education is the search of technologies to improve the content and organization of physical education process, the formation of a valuable attitude to its means, the formation of a healthy lifestyle (Zheleznyak, Lejfa \& Perel'man, 2015). The materials and facts obtained in the course of scientific research will help to identify barriers to the use of physical exercises by students for health-improving purposes, the reasons for their lack of desire to use self-development skills, as well as to identify effective methods to solve physical education problems at university.

In recent years, an increasing number of specialists are paying attention to the development of a concept of person-centered physical education, aimed to form attitudes towards health protection among students, to improve their conditional physical fitness and ultimately improve their health (Belykh, 2015). These concepts should be released through a system of pedagogical, psychological, sports, and physical education technologies. According to Kuzmina, Lebedinskij, and Shvachun, (2020) in current circumstances, only a person-centered approach in physical education integrated into professional training of future specialists solves the problems of forming a motivational-valuable attitude to physical culture, and mindset on maintaining a healthy lifestyle. According to Kadyrov (2013), an elective physical education, or "ability to self-design" taking into account the optimal level of physical activity for everyone involved, provides a constant nature of training process and provides a healing effect. According to M.Ivanovic, Samardzic and Ivanovic (2011), the consideration of individual characteristics while organizing the process of physical education of students is the highest priority. The use of these technologies has a positive effect on the formation of the mindset and motivational-valuable attitude of students to physical education, improves their mental state and physical fitness (Karavan \& Kadyrov, 2019).

The experimental confirmation of the use of technologies in the process of physical education is the subject of research by many authors (Borisova, 2006; Avsaragov, 2010). So, Konovalova (2013) revealed an improvement in physical development, physical fitness, and level of students' health, identified by the method of Apanasenko after introduction of cardio workouts combinations into female's educational process, performed with control 
of the intensity of the load according to heart rate and power loads using the Isotonic system, with an intensity of muscle activation in the range of $30-70 \%$. Positive dynamics were also revealed in the physical fitness of male students using the fitness concept, cardio training in combination with strength exercises. Yesselbayeva, Abdykadyrova, Tverdovskaya, Otaraly and Alikey (2015) revealed improved functional and physical fitness as well as academic performance of students of 1-3 courses experimentally substantiating the introduction of an individual health-improving training program, the main part of which was aerobic exercises of rhythmic gymnastics. In addition, the authors emphasize the importance of the introduction of theoretical training into teaching the "Physical Education" discipline.

According to the studies of the authors analyzed above, great attention should be paid to the content of classes and correspondence of the proposed loads to the set goals in organizing practical classes in physical education, since not every exercise solves health problems. So, according to Prontenko et al. (2017), only a load of optimal intensity, duration, and frequency gives the desired training and health effect. Plisko, Radziievskyi and Bondarenko (2018) believe that exercise should not be episodic, but should be consistent and continuous. Also, the main requirements for the exercises are their long duration, the involvement of large muscle groups, the rhythmic nature of muscle activity. These requirements, according to Romanchenko (2006), are met by cyclic exercises of an aerobic nature, which contribute to the increase of potential capabilities of the basic body life-supporting systems and therefore improve health.

In addition to the practical exercises Harvey, Kirk and O'Donovan (2014), Bakaev, Bolotin and Aganov (2016) and Bakayev, Vasilyeva, Kalmykova and Razinkina (2018) consider that it is necessary to introduce a theoretical course that would contribute to the conscious use of physical education, increase motivation for a healthy lifestyle, and prevent injuries. All these, according to Majeric (2016), will contribute to students' awareness of the importance of physical exercise as an integral part of a healthy lifestyle. Because only a person who understands the negative consequences of low physical activity is able to maintain a sufficient level of physical condition (Kandyba et al., 2018; Prontenko et al., 2016).

Also, according to Moreno-Murcia and Hellín-Gómez (2002), attention should be paid to the formation of students' positive attitude to physical exercises through the increase of satisfaction with the quality of the classes, which, in turn, can contribute to the growth of intentions to independent physical education and sports activities. The active involvement of students in active exercise is an important tool to promote a healthy lifestyle among students (Zorio-Ferreres, Alguacil \& García-Pascual, 2018). The adoption of these measures is especially important during the period of study at university, since during this period the habits that people will adhere to for the rest of their lives are formed (Juškelienè \& Česnavičienè, 2017). 
These facts motivated us to search and implementation of effective technologies to improve the physical condition of students, increase their motivation in the active use of physical exercises in everyday life.

The purpose of this study is to find the answer to the question of how a healthimproving training program developed individually for each student, based on the use of aerobic exercise, will affect the physical and functional fitness of students.

\section{Methods}

\section{Study design and participants}

We conducted a quasi-experimental trial with a total of 45 participants from Al-Faraby Kazakh National University. Male students of the 1st year $(n=45)$, whose average age was $17.68 \pm 0.74$ years, took part in the experiment. Students were divided into two groups, control and experimental, by the independent and random selection method. Training sessions in the control group (CG) were conducted as part of the Model Curriculum and the State Compulsory Education Standard. Students of the experimental group (EG) were engaged in an individual health-improving training program, the basis of which was the Cooper (1968) running program of aerobic orientation, designed for students up to 30 years old with varying degrees of fitness. The load during the run was adjusted according to individual indicators of the optimal heart rate, which was calculated by the calculation method according to the Karvonen formula (The Oxford Dictionary of Sports Science and Medicine, 2006), with the calculation of the reserve heart rate $\left(\mathrm{HR}_{\mathrm{R}}\right)$, maximum $\left(\mathrm{HR}_{\mathrm{Max}}\right)$ and target or optimal $\left(\mathrm{RH}_{\mathrm{O}}\right)$. Moreover, to calculate the maximum heart rate, we used an updated in 2007 formula:

$$
\mathrm{HR}_{\text {Max }}=205.8-(0.685 \mathrm{x} \text { age (years)). }
$$

For the objective estimation of the proposed load correctness, we used heart rate monitors. These technical devices allowed us to create individual classes' plans, evaluate the dynamics of functional indicators, which helped to generally improve the effectiveness of classes.

The main part of class also included an isolated power load aimed to develop strength endurance of main muscle groups, as well as exercises to develop coordination, speed abilities, and flexibility of students. The program also included a theoretical part, which was carried out in form of conversations and was aimed to develop the ability to assess physical condition by students themselves, plan and construct sets of physical exercises depending on the set goals, and assess individual dynamics of physical condition. Information on the organization and methodology of conducting classes in the experimental group is presented in table 1 . 
Table 1

Description of the Experimental Health-improving Training Program

\begin{tabular}{ll}
\hline Total number of classes & 60 (30 in each semester) \\
\hline Number of classes per week & 2 \\
\hline Duration of a class & $\begin{array}{l}110 \text { minutes (100 min practical part + } 10 \text { min theo- } \\
\text { retical part) }\end{array}$ \\
\hline Heart rate during exercise (in\% of the & $100-120$ heart rate $(16 \%)$ \\
total time of the practical class) & $120-140$ heart rate $(34 \%)$ \\
& $140-160$ heart rate $(50 \%)$ \\
\hline \multicolumn{1}{c}{ Duration of the class parts (in \% of the total lesson time) } \\
\hline Warm up & $8 \%$ \\
Main part: & $74 \%$ \\
- aerobic component & $50 \%$ \\
- cool down & $8 \%$ \\
- power component & $16 \%$ \\
Stretching exercise & $8 \%$ \\
Theoretical part & $10 \%$ \\
\hline Control tests & $1.2-3$ week of the $1^{\text {st }}$ semester \\
& $2.14-15$ week of the $2^{\text {nd }}$ semester \\
\hline Experiment Dates & September $2018-$ May 2019 \\
\hline
\end{tabular}

\section{The sample of variables}

Evaluation of the effectiveness of the program proposed by us was carried out by:

- dynamics of physical fitness, which were detected using the following tests: $3000 \mathrm{~m}$ and 100m run, standing long jump, pull-ups (Meshcheryakov \& Egorychev, 2018);

- degree of compliance of the obtained indicators with the regulatory requirements of national standards of physical fitness - the National Readiness Level (NRL) and the Presidential level of the Presidential Physical Fitness Tests;

- level of the functional state of the cardiovascular system and adaptation of students' bodies in response to the standard load of the Martine-Kushelevsky test, the results of which were evaluated by the standard method (Bujkova, 2017) and its dynamics during the experiment. Heart rate was measured using a SigmaPC 26.14 heart rate monitor. Blood pressure was measured using a mechanical tonometer, while the tonometer cuff was placed on the left shoulder.

\section{Ethical considerations}

The experiment was conducted with the permission of the Ethics Committee of the Kazakh Academy of Sports and Tourism (dated 09.09.18, No. 09-01-08-500). Voluntary informed consent was a compulsory tenancy condition for students' participation in the experiment. The participants in the experiment received all the answers to their questions 
about the experiment. The confidentiality of the data of the participants in the experiment and other ethical standards were respected.

\section{Data analysis}

Processing of the obtained results was carried out using the statistical package IBMSPSSStatistics 25 . The following statistical characteristics were analyzed: arithmetic mean value, standard deviation, significance of changes in average values. The Kolmogorov-Smirnov normality test was used to examine if variables are normally distributed. Student t-test for independent samples was applied to determine differences between students' scores in the experimental and control groups, and paired samples $t$ test was used to determine differences between the first and second measurements. Changes were considered significant at 5\% significance level.

\section{Results}

There were changes indicating an improvement in students' physical fitness in both groups of students, according to most indicators, by the end of the academic year, as shown in table 2. However, their nature was more shown in the experimental group compared to the control group. An exception is the performance in $3000 \mathrm{~m}$ run, which significantly improved only in the experimental group.

Table 2

Dynamics of Indicators of Physical Fitness of 1st Year Students

\begin{tabular}{|c|c|c|c|c|c|c|c|c|}
\hline \multirow[t]{3}{*}{ Indicators } & \multicolumn{4}{|c|}{ Control group $(n=23$} & \multicolumn{4}{|c|}{ Experimental group $(\mathrm{n}=22)$} \\
\hline & Mean \pm SD & Mean $\pm S D$ & \multirow{2}{*}{$\mathbf{t}$} & \multirow{2}{*}{$\mathbf{p}$} & \multirow{2}{*}{$\begin{array}{c}\text { Mean } \pm S D \\
\text { Pre-test }\end{array}$} & \multirow{2}{*}{$\frac{\text { Mean } \pm \text { SD }}{\text { Post-test }}$} & \multirow{2}{*}{$\mathbf{t}$} & \multirow{2}{*}{$\mathbf{p}$} \\
\hline & Pre-test & Post-test & & & & & & \\
\hline $100 \mathrm{~m}(\mathrm{sec})$ & $14.0 \pm 0.7$ & $13.6 \pm 0.6$ & 1.7 & .06 & $13.8 \pm 0.8$ & $12.6 \pm 0.6$ & 12.2 & .001 \\
\hline $3000 \mathrm{~m}(\mathrm{sec})$ & $1098.3 \pm 1.1$ & $1104.4 \pm 2.3$ & 1.4 & .08 & $1062.0 \pm 1.4$ & $774.5 \pm 0.8$ & 12.8 & .000 \\
\hline $\begin{array}{l}\text { Standing long } \\
\text { jump }(\mathrm{cm})\end{array}$ & $228.1 \pm 11.6$ & $240.3 \pm 10.5$ & 5.7 & .001 & $229.7 \pm 18.5$ & $250.8 \pm 14.5$ & 9.5 & .001 \\
\hline $\begin{array}{l}\text { Pull-ups } \\
\text { (number) }\end{array}$ & $11.5 \pm 3.3$ & $13.4 \pm 3.9$ & 3.6 & .001 & $10.5 \pm 2.8$ & $16.6 \pm 3.8$ & 10.9 & .000 \\
\hline
\end{tabular}

So, the results of students of the experimental group in the $100 \mathrm{~m}$ run improved on average by $8.6 \%(p=0.001)$, in the standing long jump by $8.4 \%(p=0.001)$, in the $3000 \mathrm{~m}$ run by $27.1 \%(\mathrm{p}=0.000)$, and in the pull-ups by $36.7 \%(\mathrm{p}=0.000)$. In the control group, results in the 100 -meter run improved by $2.9 \%(\mathrm{p}=0.06)$, and significant changes were observed only in standing long jump by $5.1 \%(\mathrm{p}=0.001)$ and pull-ups by $14.2 \%(\mathrm{p}=0.001)$. 
The degree of reliability of the difference in the indicators between groups of students before and after the experiment is shown in table 3.

Table 3

The Significance of the Difference between the Groups of Tested

\begin{tabular}{lcccc}
\hline \multirow{2}{*}{ Indicators } & \multicolumn{2}{c}{ Before the experiment } & \multicolumn{2}{c}{ After the experiment } \\
\cline { 2 - 5 } & t-test & $\mathbf{p}$ & t-test & $\mathbf{p}$ \\
\hline $100 \mathrm{~m}$ & 0.71 & 0.49 & 6.69 & 0.000 \\
$3000 \mathrm{~m}$ & 0.63 & 0.41 & 13.2 & 0.000 \\
Standing long jump & 0.35 & 0.73 & 2.69 & 0.014 \\
Pull-ups & 0.27 & 0.071 & 2.49 & 0.021 \\
\hline
\end{tabular}

Table 4 presents the data on the compliance of students' physical fitness indicators at the end of the experiment with the national standards applicable in the country (Presidential Physical Fitness Tests (PPFT)). By the end of the experiment, the number of students who had mastered the regulatory requirements of PPFT also increased in both groups of students. The exception is the results in the test $3000 \mathrm{~m}$ run in the control group, whose normative requirements neither at the beginning nor at the end of the experiment were able to master any student. The percentage of students who met the regulatory requirements of PPFT in the experimental group was higher than in the control group (table 4).

Table 4

Compliance of Physical Fitness Indicators of Students in the Control and Experimental Groups with the Regulatory Requirements of the National Readiness Level (NRL) and the Presidential Level (PL) of the Presidential Physical Fitness Tests (PPFT) before and after the Experiment

\begin{tabular}{|c|c|c|c|c|c|c|c|c|c|c|c|c|c|}
\hline \multirow{3}{*}{ Group } & \multirow{3}{*}{ Stages } & \multicolumn{12}{|c|}{ Control Exercises } \\
\hline & & \multicolumn{3}{|c|}{$100 \mathrm{~m}(\%)$} & \multicolumn{3}{|c|}{3000 m (\%) } & \multicolumn{3}{|c|}{$\begin{array}{c}\text { Standing long jump } \\
(\%)\end{array}$} & \multicolumn{3}{|c|}{$\begin{array}{l}\text { Body lifting from a } \\
\text { supine position (\%) }\end{array}$} \\
\hline & & $\begin{array}{l}\text { Did } \\
\text { not } \\
\text { pass }\end{array}$ & NRL & PL & $\begin{array}{c}\text { Did } \\
\text { not } \\
\text { pass }\end{array}$ & NRL & PL & $\begin{array}{l}\text { Did } \\
\text { not } \\
\text { pass }\end{array}$ & NRL & PL & $\begin{array}{c}\text { Did } \\
\text { not } \\
\text { pass }\end{array}$ & NRL & $\mathrm{PL}$ \\
\hline \multirow[t]{2}{*}{ Control } & before & 81.8 & 13.6 & 4.6 & 100 & - & - & 95.7 & 4.3 & - & 82.6 & 13.1 & 4.3 \\
\hline & after & 69.6 & 25.8 & 4.6 & 100 & - & - & 65.2 & 30.4 & 4.4 & 74.0 & 13.0 & 13.0 \\
\hline \multirow{2}{*}{$\begin{array}{l}\text { Experi- } \\
\text { mental }\end{array}$} & before & 79.6 & 16.1 & 4.3 & 100 & - & - & 73.9 & 26.1 & - & 95.7 & 4.3 & - \\
\hline & after & 13.1 & 30.4 & 56.5 & 47.8 & 47.8 & 4.4 & 30.4 & 21.7 & 47.9 & 17.4 & 43.5 & 39.1 \\
\hline
\end{tabular}

Also, we revealed a satisfactory reaction of students' bodies in both groups to the load, however, the nature of recovery processes indicated poor adaptability of students to the 
load of the Martine-Kushelevsky test at the beginning of the pedagogical experiment (table 5).

Table 5

Indicators Characterizing the Activity of the Cardiovascular System of Male Students Underthe Influence of the Martine-Kushelevsky Test, before and after the Pedagogical Experiment

\begin{tabular}{|c|c|c|c|c|c|c|c|}
\hline \multirow{3}{*}{$\begin{array}{l}\text { Indica- } \\
\text { tors }\end{array}$} & \multirow{3}{*}{$\begin{array}{l}\text { Recove- } \\
\text { ry time }\end{array}$} & \multicolumn{3}{|c|}{ Control group $(n=23)$} & \multicolumn{3}{|c|}{ Experimental $(n=22)$} \\
\hline & & Mean \pm SD & Mean \pm SD & & Mean \pm SD & Mean \pm SD & \\
\hline & & before & after & $\mathbf{p}$ & before & after & $\mathbf{p}$ \\
\hline \multirow{4}{*}{$\begin{array}{l}\text { HR, } \\
\text { bpm }\end{array}$} & rest & $76.1 \pm 2.0$ & $71.8 \pm 5.4$ & $>.05$ & $80.4 \pm 1.9$ & $64.5 \pm 2.0$ & $<.05$ \\
\hline & $1 \mathrm{~min}$ & $114.5 \pm 2.9$ & $116.1 \pm 3.4$ & $>.05$ & $115.8 \pm 4.3$ & $98.4 \pm 1.2$ & $<.05$ \\
\hline & $2 \min$ & $102.3 \pm 3.2$ & $98.4 \pm 4.6$ & $>.05$ & $103.9 \pm 1.3$ & $84.3 \pm 2.2$ & $<.05$ \\
\hline & $3 \mathrm{~min}$ & $91.3 \pm 5.1$ & $89.6 \pm 7.4$ & $>.05$ & $93.4 \pm 2.5$ & $72.1 \pm 1.1$ & $<.05$ \\
\hline \multirow{4}{*}{$\begin{array}{l}\text { SBP, } \\
\mathrm{mm} \mathrm{Hg}\end{array}$} & rest & $118.1 \pm 3.2$ & $116.3 \pm 2.4$ & $>.05$ & $115.1 \pm 1.9$ & $116.9 \pm 0.2$ & $>.05$ \\
\hline & $1 \mathrm{~min}$ & $139.1 \pm 4.0$ & $132.4 \pm 3.2$ & $>.05$ & $141.3 \pm 6.2$ & $126.4 \pm 3.1$ & $<.05$ \\
\hline & $2 \mathrm{~min}$ & $132.0 \pm 5.3$ & $134.0 \pm 3.3$ & $>.05$ & $129.6 \pm 2.6$ & $119.1 \pm 1.4$ & $<.05$ \\
\hline & $3 \mathrm{~min}$ & $127.1 \pm 3.1$ & $119.5 \pm 1.1$ & $>.05$ & $122.3 \pm 5.2$ & $118.7 \pm 3.3$ & $<.05$ \\
\hline \multirow{4}{*}{$\begin{array}{l}\text { DBP, } \\
\text { mm Hg }\end{array}$} & rest & $68.7 \pm 1.8$ & $68.7 \pm 1.8$ & $>.05$ & $70.1 \pm 1.9$ & $71.3 \pm 3.6$ & $>.05$ \\
\hline & $1 \mathrm{~min}$ & $70.1 \pm 1.8$ & $73.8 \pm 4.3$ & $>.05$ & $69.4 \pm 3.2$ & $65.1 \pm 2.1$ & $>.05$ \\
\hline & $2 \min$ & $71.5 \pm 1.4$ & $74.0 \pm 2.2$ & $>.05$ & $70.3 \pm 2.0$ & $66.7 \pm 4.2$ & $>.05$ \\
\hline & $3 \mathrm{~min}$ & $66.9 \pm 1.4$ & $71.8 \pm 4.5$ & $>.05$ & $67.4 \pm 2.0$ & $70.1 \pm 3.3$ & $>.05$ \\
\hline \multirow{4}{*}{$\begin{array}{l}\mathrm{PP}, \\
\mathrm{mm} \mathrm{Hg}\end{array}$} & rest & $45.3 \pm 1.9$ & $44.1 \pm 1.4$ & $>.05$ & $44.3 \pm 3.2$ & $40.3 \pm 3.2$ & $>.05$ \\
\hline & $1 \mathrm{~min}$ & $72.1 \pm 4.1$ & $70.0 \pm 3.5$ & $>.05$ & $73.6 \pm 5.3$ & $70.6 \pm 5.3$ & $>.05$ \\
\hline & $2 \min$ & $60.3 \pm 5.5$ & $54.1 \pm 2.1$ & $<.05$ & $59.6 \pm 3.5$ & $59.6 \pm 3.5$ & $>.05$ \\
\hline & $3 \mathrm{~min}$ & $80.4 \pm 4.5$ & $70.3 \pm 3.7$ & $<.032$ & $75.5 \pm 4.7$ & $50.3 \pm 4.7$ & $<.05$ \\
\hline \multicolumn{2}{|c|}{ Recovery time, min } & $5.2 \pm 0.9$ & $4.6 \pm 1.3$ & $>.05$ & $6.3 \pm 0.4$ & $3.4 \pm 0.8$ & $<.05$ \\
\hline
\end{tabular}

Note: HR - heart rhythm, SBP - systolic blood pressure, DBP - diastolic blood pressure, $\mathrm{PP}$ - pulse pressure

At the beginning of the experiment, the dynamics of individual heart rate values in the recovery period testified to the reduced functional capabilities of the students' bodies. So, only 6 students of the control (26\%) and 4 students of the experimental group (18\%), heart rate indicators recovered to their original values at the 3rd minute of recovery. Also, by the end of the 3rd minute, most of the analyzed indicators, except of the DBP values, exceeded the initial values. Thus, the PP values of $12 \%$ of students in the control and $13 \%$ of the experimental groups were higher than the initial ones, respectively, by $30.8 \pm 0.01 \%(\mathrm{t}=2.55, \mathrm{p}<0.05)$ and $32.4 \pm 0.05 \%(\mathrm{t}=2.84, \mathrm{p}<0.05)$. This was mainly due to the values of SBP, which still exceeded the initial values by $11.50 \pm 1.44 \%$ in the control and by $12.01 \pm 2.01 \%$ in the experimental group. In general, the dynamics of the analyzed parameters indicate an adequate load of the reaction of the cardiovascular system; however, the nature of the recovery processes indicates poor adaptability of the 
students' body loads. This is also indicated by the total recovery time after exercise, which was $5.2 \pm 0.9 \mathrm{~min}$ and $6.3 \pm 0.4 \mathrm{~min}$ in the control and experimental groups, respectively.

Also, at the beginning of the experiment, a normal response to the load was detected only at $22 \%$ of the tested students in the control and experimental groups. The reaction of the remaining students of both groups was assessed as unfavorable. So, 35\% of students in the control and $37 \%$ in the experimental group at the beginning of the experiment revealed a "hypotonic" type of reaction to the load. For these students, during the recovery period, the values of heart rate and SBP slightly increased, and the DBP indicators sharply decreased. This indicates a weak fitness of the tested students, significant energy costs, and inefficient heart function. Also, 35\% of students in the control and $37 \%$ in the experimental groups showed changes characteristic of the "hypertonic" type of reaction to the load. This type of reaction, which is characterized by a sharp increase in heart rate and SBP and an increase in DBP, is evidence of poor body adaptation to stress and significant heart overloads. The remaining students also revealed signs of insufficient training, and a "stepwise" type of reaction to the load, that is, an increase in all the studied parameters in the recovery period.

By the end of the pedagogical experiment, an improvement in the response to the load of the sample and a reduction in the recovery time were revealed, which was more shown in the experimental group comparing to the control group (table 3). So, by the end of the pedagogical experiment, a statistically significant decrease in heart rate indicators at rest by $19.8 \%$ was observed $(\mathrm{p}<0.05)$ in the experimental group. An improvement in the response of the cardiovascular system in response to the load of the sample was also revealed, which was expressed in lower rates of heart rate, SBP and DBP and recovery time after exercise compared to the values before the experiment. Also, in the experimental group, the number of students with a normal response and good adaptation to the sample load increased from $22 \%$ at the beginning of the experiment to $73 \%$ by the end of the experiment (Figure 1).

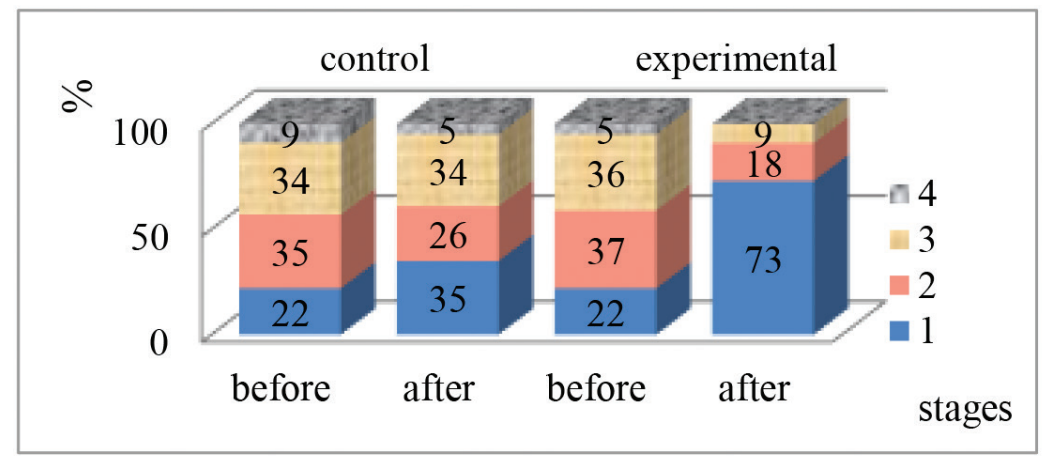

Note: Types of reaction to the load: 1 - normotonic; 2 - hypotonic; 3 - hypertonic; 4 - stepped

Figure 1. Types of reaction of the cardiovascular system of young students to the load of the Martine-Kushelevsky test before and after the experiment 
Accordingly, a decrease in the number of students with unfavorable dynamics of indicators characterizing the activity of the cardiovascular system in the recovery period was revealed.

In the control group, was found a tendency to improve the body's response to the load and shorten the recovery period by the end of the pedagogical experiment compared to its beginning. Thus, a decrease in heart rate at rest and after exercise and recovery time after exercise was revealed. Also, the number of students with an adequate response to the load increased, and the number of students with unfavorable dynamics in the recovery period slightly decreased. However, all these changes were minor and statistically unreliable.

\section{Discussion}

The aim of this work is to find an answer to the question of how a health-improving training program developed individually for each student, based on the use of aerobic exercise, will affect on physical and functional fitness of students. Studies show (Podstawski, Honkanen, Choszcz \& Boraczyński, 2013) the level of students' motor abilities, physical and functional fitness depends on the type of physical education and the activities in which they participate. Exercise will not bring the desired effect if physical activity is less than the individual abilities of the students (Bosquet, Merkari, Arvisais \& Aubert, 2008). On the contrary, the use of constant peak load leads to the failure of adaptation mechanisms, which may result in destructive changes of internal organs work (Pochueva \& Smetanin, 2019).

The results of our study confirmed the opinion of other researchers that the success of physical education depends on the proper organization of this process (Popescu, 2014). While analyzing the results of this study, we found an improvement in all parameters characterizing the physical and functional fitness of all students who participated in the study. However, these dynamics were more shown and statistically significant in the group engaged in the experimental methodology, compared to those engaged in the traditionally accepted methodology. Thus, the use of experimental methods has improved students' results in running $(100 \mathrm{~m}$ and $3000 \mathrm{~m})$, where the greatest positive dynamics revealed. In "standing long jump" and "pull-ups" exercises, students' results improved to a lesser extent. The results obtained may be determined by the fact that in practical exercises the main time was devoted to performing the aerobic-oriented running load, and the share of exercises for the development of speed-strength capabilities and strength endurance was less. In the control group, a significant improvement in indicators was found only in "standing long jump" and "pull-ups" exercises.

In addition, increased the level of students' master skills in national standards, the Presidential tests of physical fitness in both groups by the end of the experiment. The exception is $3000 \mathrm{~m}$ run, the regulatory requirements of which were not mastered by students in the control group either before or after the experiment. 
Our data correlate with data from Avsaragov (2010) and Mustedanagić, Bratić, Milanović and Pantelić, (2016), which revealed an improvement in the parameters of physical development, physical and functional fitness, and an improvement in the aerobic capacity of students as a result of using an individual model of aerobic exercise. Borisova (2006) came to the same conclusion in her research, which noted that the application of the methodology based on the individual characteristics of students led to increased physical fitness and improved students' results in following exercises, "standing long jump" "100, 1000 and $2000 \mathrm{~m}$ run", "throwing a stuffed ball" and qualitatively reflected on the motives for physical exercises.

Improvement in the functional state of students was also revealed by the end of the pedagogical experiment. These changes were also more shown in the experimental group compared to the control group.

A study by other authors (Phaswana, Ramalivhana \& Amusa, 2015) showed that most students had low cardiorespiratory endurance, and the prevalence of overweight and obesity among students was high.

Our study showed that during the experimental period, one out of three students' revealed changes typical for "hypertonic" reaction to the load. This type of reaction, which is characterized by a sharp increase in heart rate and SBP and an increase in DBP, is evidence of poor body adaptation to stress and significant heart overloads (Bujkova, 2017).

By the end of the experiment, the number of students with a normotonic reaction of the cardiovascular system to the load increased in the experimental group and, accordingly, the number of students with unfavorable options for the body's reaction to the load decreased. Also, generally in the group, the time of the recovery period decreased, as well as a decrease in heart rate indicators both at rest and after exercise. This indicates the economization of the cardiovascular system and an increase in the degree of students' body fitness in the experimental group.

Similar data were obtained by Kamaev and Kamaeva (2010), who noted an improvement in the performance of the cardiovascular and respiratory systems, as well as the results of students in the "standing long jump" and "2000 meters run" when using cross-training in combination with exercises performed on training devices. Similar results have been identified by Feofilaktov (2005), Kostić, Đuračković, Miletić and Mikalaĉki, (2006).

Consequently, the results of the analysis of literature and our own pedagogical experiment allow us to conclude the effectiveness of the use of personality-oriented healthimproving training programs. The application of this program revealed an improvement in such parameters of physical fitness as endurance, speed-strength capabilities, and strength endurance. In addition, the experimental program had a positive effect on the students' functional fitness and contributed to the economization of the cardiovascular system of students in the experimental group both at rest and after standard load, as evidenced by a significant decrease in heart rate, systolic blood pressure and diastolic blood pressure at rest and after exercise; the nature of the dynamics of the indicators in the recovery period and the total recovery time. 
In addition, the study made it possible for students to objectively learn their individual functional and motor skills, which improved their motivation for regular exercise. This, in turn, affected on the attendance of students of classes on disciplines in the experimental group.

\section{Limitation}

The limitations of this study are important to note. Due to the quasi-experimental design used in the study, the study sample and its distribution into groups were nonrandom. Due to the absence of this coincidence, we cannot be sure and conclusive that the changes in the dependent variables were due to the manipulation of the independent variable in the experimental group, indicated as group with an educational program has been drawn up. Nevertheless, in the social sciences, especially in the field of education, the researcher often has to work with existing groups simply by not being able to randomly select groups and assign subjects to them (Leedy \& Ormrod, 2010), so a control group study and primary measurement of dependent variables were used to validate our study data.

Another limitation of the study would be that only male students participated in the study. According to many studies, men are more physically active than female students at the student age, which may have meant that they were more motivated to participate in this experimental group and that this also, affected the results of the study. Therefore, the application of this program in the group of female students could help to assess the influence of gender as a factor on the applied intervention. Also, we would think that the number of dependent variables could be extended to gain deeper insights from an educational point of view. Recording variables such as students' mindset, motivation, and academic achievement physical activity self-regulation skills through an experimental program could better explain the impact of individual access to planning and regulating student physical activity on student personality maturity related to health care and enhancement.

\section{Conclusion and Implications}

According to the research data, it can be stated that the introduction of an individual approach to the planning and organization of the educational process has a positive effect on the effectiveness of the physical education process at university. Physical education programs, in which physical activity is regulated in accordance with the functional readiness of an individual student using a device for measuring heart rate, improve students' physical performance and physical fitness and allow better assessment of students' adaptation to physical activity. The results of this study can help university teachers to improve their students' health and fitness by focusing more on methods and tools that 
help students to understand the importance of individual exercises in achieving health goals. This would allow students to acquire the knowledge and skills of self-control that are important to students in planning independent physical activity programs.

Generally, the analysis of the obtained data once again proves the need for further larger-scale research in the field of incorporating individual health-improving training technologies into the educational process of physical education.

\section{Conflicts of interest}

The authors declare that there are no conflicts of interests.

\section{References}

Apanasenko, G. L., \& Naumenko, R. T. (1988). Fizicheskoe zdorov'e i maksimal 'naya aerobnaya sposobnost' individa [Physical health and maximal aerobic ability of an individual]. Teoria I Praktika Fizicheskoy Kultury, 4, 23-30.

Avsaragov, G. R. (2010). Fizicheskoe vospitanie studentov vuzov v razlichnyje periody uchebnogo processa. [Physical education of university students at various periods of the educational process]. (Publication No. 04201006166) [Doctoral dissertation, Kama State Academy of Physical culture, Sport and Tourism] DisserCat Open. https://www.dissercat.com/content/ fizicheskoe-vospitanie-studentov-vuzov-v-razlichnye-periody-uchebnogo-protsessa

Bakaev, V. V., Bolotin, A. E., \& Aganov, S. S. (2016). Physical training complex application technology to prepare rescuers for highland operations. Teoria I Praktika Fizicheskoy Kultury, 6, 6-8.

Bakayev, V., Vasilyeva, V., Kalmykova, S., \& Razinkina, E. (2018). Theory of physical culture - a massive open online course in educational process. Journal of Physical Education and Sport (JPES), 18(1), 293-297.

Barnett, N., Clark, M., Linkletter, C., Loxley, M., Rogers, M., \& Ott, M. (2013). Peer associations for substances use and exercise in a college student social network. Health Psychology, 33(10), 1134-1142. https://doi.org/10.1037/a0034687

Batrymbetova, S. A. (2008). Mediko-socialnaya harakteristika studentov i nauchnoe obosnovanie koncepcii ohrany ih zdorovya (na primere g. Aktobe Respubliki Kazahstan) [Medical and social characteristics of students and the scientific substantiation of the concept of protecting their health (for example, the city of Aktobe of the Republic of Kazakhstan)]. (Publication No. 003447536) [Doctoral dissertation, N. A.Semashko National research institute of public health] DisserCat Open. https://www.dissercat.com/content/mediko-sotsialnayakharakteristika-studentov-i-nauchnoe-obosnovanie-kontseptsii-okhrany-ikh-

Belykh, S. I. (2015). Experimental verification of the concept and program of personality centered physical education of university students. Teoria I Praktika Fizicheskoy Kultury, 5, 100-104. 
Bosquet, L., Merkari, S., Arvisais, D., \& Aubert, A. E. Is heart rate a convenient tool to monitor overreaching? A systematic review of the literature. British Journal of Sports medicine, 42 (9), 709-714.

Borisova, O. V. (2006). Texnologiya differecirovaniya fizicheskoj podgotovki studentov vuzov na osnove ucheta sootnosheniya somaticheskix i psixologicheskix tipov [The technology of differentiating physical training of university students based on the ratio of somatic and psychological types] [PhD thesis, Volgograd National academy of physical culture] DisserCat Open. https://www.dissercat.com/content/tekhnologiya-differentsirovaniya-fizicheskoipodgotovki-studentov-vuzov-na-osnove-ucheta-soo

Bujkova, O. M., \& Bulnaeva, G. I. (2017). Funkcional'nye proby v lechebnoj I massovoj fizicheskoj kult'ture [Functional tests in medical and mass physical education]. Irkutsk: Irkutsk State Medical University.

Cooper, K. H. (1968). Aerobics. New York, Philadelphia: M. Evans and Bantam Books.

Eichorn, L., Brune, K., Short, T., \& Abraham, S.P. (2018). Factors that affect exercise habits of college students. Journal of Education and Development, 2 (1), 20-30. doi:10.20849/jed.v2il.327

El Ansari, W., Stock, C., John, J., Deeny, P., Phillips, C., \& Mabhala, A. (2011). Health promoting behavior and lifestyle characteristic of students at seven universities in the UK. Central European Journal of Public Health, 19(4), 197-204.

Feofilaktov, V.V. (2005). Sravnitelnyy analiz innovatsionnykh tekhnologiy fizicheskoy podgotovki studentov gumanitarnykh vuzov na osnove monitoringa fizicheskogo razvitiya [Comparative analysis of innovation technologies for physical training of humanitarian universities students based on monitoring of physical development]. (Publication No. 22667) [PhD thesis, Russian national university of physical culture, sport and tourism] DisserCat Open. https:// www.dissercat.com/content/sravnitelnyi-analiz-innovatsionnykh-tekhnologii-fizicheskoipodgotovki-studentov-gumanitarny

Gosudarstvennyj obshcheobyazatel'nyj standart vysshego obrazovaniya [State compulsory standard of higher eduction] (Order No 604 of 31 October 2018). The Minister of Education and Science of the Republic of Kazahstan. Retrieved from: http://adilet.zan.kz/rus/docs/V1800017669

Graf, H. M., \& Welle, P. D. (2014). Effective lifestyle habits and coping stress tolerance among college students. American Journal of Health Education, 42(2), 96-105. https://doi.org/10.10 80/19325037.2011.10599177.

Harvey, S., Kirk, D., \& O’Donovan, T. M (2014). Sport education as a pedagogical application for ethical development in physical education and youth sport. Sport, Education and Society, 19(1), 41-62. doi: https://doi.org//10.1080/13573322.2011.624594

Haase, A., Steptoe, A., Sallis, J. F., \& Wardle, J. (2004). Leisure-time physical activity in university students from 23 countries: associations with health beliefs, risk awareness, and national economic development. Preventive Medicine, 39(1), 182-190. doi: 10.1016/j.ypmed.2004.01.028

Ivanovic, M., Samardzic, B., \& Ivanovic, U. (2011). Functional abilities as predictors of preadolescent students' athletic results outcome. Sport Mont, IX (31-32-33), 3-13.

Ivashchenko, O. V., Yermakova, T. S., Cieslicka, M., \& Muszkieta, R. (2015). Discriminant analysis as method of pedagogic control of 9-11 forms girls' functional and motor fitness. Journal of Physical Education and Sport (JPES), 15(3), 576-581. doi:10.7752/jpes.2015.03086 
Juškelienė, V., \& Česnavičienė, J. (2017). Lietuvos edukologijos universiteto pirmo kurso studentų fizinis aktyvumas ir ji lemiantys veiksniai [Physical activity and its determinants among first year students of Lithuanian University of Educational Sciences]. Pedagogika, 128(4), 217-231.

Kandyba, T. P., Kyslenko, D., Yukhno, Yu., Zhukevych, I., Bondarenko,V., \& Radzievskii, R. (2018). Improving the physical qualities of students in higher educational establishments of Ukraine on guard activity via circular training. Journal of Physical Education and Sport (JPES), 18(2), 1065-1071.

Kady`rov, R. M., \& Blaxin, G.N. (2013). Teoreticheskie osnovy' soderzhaniya i normativov fizicheskoj podgotovki voennosluzhashhix [Theoretical basis of the content and standards of physical training of military personnel]. Volgograd: Volgograd Institute of physical culture.

Kamaev, O. I., \& Kamaeva, E. K. (2010). Osobennosti ispol 'zovaniya kompetentnostnogo podxoda v zdorov'eformiruyushhix texnologiyax v usloviyax vuza [Features of using the competency-based approach in health-forming technologies in a university]. Physical Education of Students, 4, 37-39.

Karavan, A. V. \& Kadyrov, R. M. (2019). Elective physical education service design course for university students. Teoria I Praktika Fizicheskoy Kultury, 11, 54-59.

Kiseleva, I. V. (2010). Nauchnoe obosnovanie organizacionnoj modeli oxrany' zdorov'ya studentov. [Scientific substantiation of the organizational model of student health]. (Publication No. 003494408) [PhD thesis, Kazan national medical university] Russian National Library Open. https://search.rsl.ru/ru/record/01003494408

Konovalova, L. Al. (2013). Fitness technology in physical education of students. Russian Journal of Education and Psychology, 7 (27), 26. Retrieved from: https://cyberleninka.ru/article/n/ fitness-technology-in-physical-education-of-students

Kostić, R., Đuračković, R., Miletić, Đ., \& Mikalaĉki, M. (2006). Changes in the cardiovascular fitness and body composition of women under the influence of the aerobic dance. Physical Education and Sport. Facta Universitatis Series. 4(1), 59-71.

Kuzmina, O. I., Lebedinskij, V.Yu. \& Shvachun, O. A. (2020). Sovremenny`e texnologii pedagogicheskogo vozdejstvia i novy'e vidy' dvigatel 'noj aktivnosti v zdorov'esberezhenii stodencheskoj molodezhi. [Modern technologies of pedagogical impact and new forms of motor activity in the health saving of students]. Teoria I Praktika Fizicheskoy Kultury, 1, 14-16.

Leedy, P. D. \& Ormrod, J. E. (2010). Practical research: Planning and design (9th ed.). Upper Saddle River, NJ: Prentice Hall.

Lipošek, S., Planinšec, J., Leskošek, B. \& Pajtler, A. (2018). Physical activity of university students and its relation to physical fitness and academic success. Annales Kinesiologiae, 9 (2), 89-104.

Majeric, M. (2016). The importance of sport in students' lives and the frequency of sport participation among students - gender differences. Sport Mont, 14(2), 3-6.

Meermanova, I. B., Kojgel'dinova, Sh. S., \& Ibraev, S. A. (2017). Sostoyanie zdorov'ya studentov, obuchayushhixsya v vy'sshix uchebny'x zavedeniyax [The health status of students studying in high school]. Mezhdunarodny' jZhurnal Prikladny'x i Fundamental 'ny'x Issledovanij, 2(2), 193-197.

Meshcheryakov, S. P., \& Egorychev, A. O. (2018). Monitoring fizicheskoj podgotovlennosti studentov. [Monitoring physical fitness of students]. Moscow: Publishing Center of the Russian State University of Oil and Gas named after I. M. Gubkin. 
Molodcov, S. A. \& Kamaev, I. A. (2001). Rol faktorov riska v obraze jizny studentov PTU i tehnikumov, kak medico-socialnaya problema [The role of rick factors in the lifestyle of vocational school and technical school students as a medical and social problem]. Gumanitarniye Metodi Issledovaniya v Medicine: Sostoyaniya i Perspektivi, 5(45), 286-290.

Moreno-Mutcia, J. A., \& Helliín-Gómez, P. (2002). Es importante la educació física? Su valoración según la edad del alumno y el tipo de centro [Is physical education important? Its assessment according to the age of the student and the type of center]. Revista Internacional de Medicina y Ciencias de la Actividad Física y de Deporte, 2(8), 298-319.

Mustedanagić, J., Bratić, M., Milanović, Z., \& Pantelić, S. (2016). The effect of aerobic exercise program on the cardiorespiratory fitness and body composition of female college students. Physical Education and Sport. Facta universitatis Series. 29(14), 145-158.

Norkus, A. (2012). Healthy lifestyle in Lithuanian student population: educational diagnostic approach. Summary of Doctoral Dissertation. Šiauliai: Šiauliai university.

Phaswana, M., Ramalivhana, F. W, \& Amusa, L. O. (2015). Body composition and cardiorespiratory endurance profiles of students at the centre for biokinetics, recreation and sport science. African Journal for Physical, Health Education, Recreation and Dance (AJPHERD), Supplement 1(2), 401-413. South Africa: University of Venda.

Pavlova, V. I., Kotova, N. V., Kislyakova, S. S., Sarajkin, D. A., \& Kamskova, Yu. G. (2016). Osobennosti fukcional'nogo sostoyaniya organizma studentov a processe obuchenich $\mathrm{v}$ medicinskom vuze [Peculiarities of the functional state of the students' organism in the process of studying at a medical university]. Sovremenny'e Problemy' Nauki i Obrazovaniya. Retrieved from http: //www.science-education.ru/ru/article/view?id=24107

Plisko, V. V., Radziievskyi, R. M., \& Bondarenko, V. V. (2018). The influence of the newest teaching methodology on the level of professional training of future security specialists. Journal of Taras Shevchenko Chernihiv National Pedagogical University, 154 (2), 41-47.

Podstawski, R., Honkanen, A., Choszcz, D., \& Boraczyński, M. (2013). Maximizing university students' motor fitness by implementing a physical education program incorporating martial arts - implicational study. Journal of Combat Sports and Martial Arts, 2(2); 4, 197-205. doi:10.5604/20815735.1090744

Popescu, A. (2014). The comparative evolution of functional cardiovascular adaptive changes in athlete and non-athlete students. Medicina Sportivâ, 10 (3), 2380-2386.

Pochueva, A. E., \& Smetanin A. G. (2019). Vidy` fizicheskix nagruzok i ix intensivnost' [Types of physical activity and their intensity]. Aktul'ny'e Issledovaniya, 2 (2), 61-63.

Poteliūnienè, S. (2010). Studentu fizini ugdyma ir sportininku rengima skatinantys veiksniai [Factors, affecting student's physical development and athletes' training]. Vilnius: VPU leidykla.

Prezidentskie testy fizicheskoj podgotovlennosti [Presidential physical fitness tests]. (Order No 1545 of 31 December 2013). The Government decree Republic of Kazakhstan. Retrieved from: http:// adilet.zan.kz/rus/docs/P1300001545 
Prontenko, K., Andreychuk, V., Martin, V., Prontenko, V., Romaniv, I., Bondarenko, V., \& Bezpaliy, S. (2016). Improvement of physical preparedness of sportsmen in Kettlebell sport on the stage of the specialized base preparation. Journal of Physical Education and Sport (JPES), 16(2), 540-545.

Prontenko, K., Kyslenko, D., Bondarenko, V., Iukhno, Iu., Radzievskii, R., Prontenko, V., \& Kizyun, O. (2017). Development of the physical qualities of future specialists in protective activities due to the use of the Kettlebell sport during studies. Journal of Physical Education and Sport (JPES), 17(2), 789-794.

Pylypei, L. P. (2013). Osobystisno oriyentovani tekhnolohiyi orhanizatsiyi navchal'no-vykhovnoho protsesu studentiv vyshchykh navchal'nykh zakladiv [Personally oriented technical organizations of the educational process of students of higher educational institutions]. Slobozhan. Nauk.-Sport. Visn., 1, 95-98.

Romanenko, S. A. (2006). Korrekciya sostoyaniya zdorov'ya studentov v processe zanyatij fizicheskoj kul 'turoj [Correction of students' health status in the process of physical exercises]. (Publication No 61:06-13/2687) [PhD thesis, St.Petersburg State university of physical culture named after P.F.Lesgaft] DisserCat Open. https://www.dissercat.com

Shagina, I. R. (2010). Mediko-sotsial'nyj analiz vliyaniya uchebnogo protsessa na sostoyanie zdorov'ya studentov meditsinskogo fakul'teta VUZa (po materialam Astrakhanskoj oblasti) [Medical and social analysis of the impact of the educational process on the health status of students of the medical faculty of the university (based on materials from the Astrakhan region)]. (Publication No 004604633) [PhD thesis, Volgograd national medical university] DisserCat Open. https://www.dissercat.com

Shahi, M., Rai, L., Adhikari, R. D., \& Sharma, M. (2013). Prevalence and factors associated with obesity among adult women of Nepal. Global Journal of Medicine and Public Health, 2 (4), 1-9. doi:10.4172/2155-6156-C7-096

Sylvia, L. G., Bernstein E. E., \& Hubbard, J. L (2014). Practical guide to measuring physical activity. Journal of the Academy of Nutrition and Dietetics, 114(2), 199-208.

The Oxford Dictionary of Sport Science and Medicine (2006). Oxford: Oxford University Press. Retrieved from https://www.oxfordreference.com/view/10.1093/acref/9780198568506.001.0001/ acref-9780198568506

Tipovaya uchebnaya programma obshcheobrazovatel'noj disicpliny «Fizicheskaya kul'tura» dlya organizacij vysshego $i$ (ili) poslevuzovskogo obrazovaniya [Typical curriculum for general education subject "Physical Culture" for organizations of higher and (or) postgraduate education]. (Order No 603 of 31 October 2018). The Minister of Education and Science Republic of Kazakhstan. Retrieved from http://adilet.zan.kz/rus/docs/V1800017651

Vlahii, O. L., \& Yachniuk, M. Yu. (2015). Analiz pokaznykiv fizychnoho stanu students'koyi molodi. Vesnyk Chernihivs'koho natsional'noho universitetu imeni Tarasa Shevchenka [Analysis of indicators of the physical condition of student youth]. Vesnyk Chernihivs'koho Natsional'noho Universitetu Imeni Tarasa Shevchenka. Fizichna Kul'tura i Sport, 129(3), 27-32. 
Zheleznyak, Yu. D., Lejfa, A. V. \& Perel 'man, Yu. M. (2015). Vzaimosvyaz' fizicheskoj aktivnostim zdorov'ya I kachestva zhizni studencheskoj molodezhi [The relationship of physical activity to students' health and life quality]. Theory and Practice of Physical Culture, 11, 41-43.

Zhigareva, O. H. (2016). Ispol'zovanie sovremennykh metodyk v fizicheskom vospitanyy studentov [The use of modern techniques in the physical education of students]. Ékonomycheskye $y$ Sotsyal'no-Hymanytarnye Yssledovanyya, 4(12), 90-94.

Zorio-Ferreres, A., Alguacil, M. Y., \& García-Pascual, F. (2018). Analysis of the opinion on physical education in high schools and the extracurricular sports practice of students and their personal environment. Journal of Physical Education and Sport (JPES), 18(3), Art 241, 1646-1653.

Yesselbayeva, A., Abdykadyrova, D., Tverdovskaya, G., Otaraly, S., \& Alikey, A. (2015). Formation of students' motorial culture by means of "Rhythmic Gymnastics". Asian Social Science, 11(18). 320-325. doi: 10.5539/ass.v11n18p320

\section{Individualios sveikatą stiprinančios programos veiksmingumas studentų fiziniam ir funkciniam parengtumui}

Svetlana Otaraly ${ }^{1}$, Alya Zhumanova ${ }^{2}$, Aibek Alikey ${ }^{3}$, Zhanna Sabyrbek ${ }^{4}$, Nataliya Shepetiuk ${ }^{5}$, Sniegina Poteliūniené ${ }^{6}$

1 Kazachstano Al-Farabi nacionalinis universitetas, Al-Farabi alëja 71, KZ-050040 Almata, Kazachstanas, otaraly17@mail.ru

Kazachstano Sporto ir turizmo akademija, Abay alëja 85, KZ-050022 Almata, Kazachstanas, otaraly17@mail.ru Kazachstano Sporto ir turizmo akademija, Abay alejja 85, KZ-050022 Almata, Kazachstanas, ALIS005@mail.ru

Kazachstano Al-Farabi nacionalinis universitetas, Al-Farabi aleja 71, KZ-050040 Almata, Kazachstanas, aaibek-82@mail.ru

L. N. Gumilovo Eurazijos nacionalinis universitetas, Satbayev g. 2, KZ-010000 Nursultanas, Kazachstanas, aaibek-82@mail.ru

4 Kazachstano Al-Farabi nacionalinis universitetas, Al-Farabi aleja 71, KZ-050040 Almata, Kazachstanas, s.zhanna@mail.ru

5 Kazachstano Al-Farabi nacionalinis universitetas, Al-Farabi aleja 71, KZ-050040 Almata, Kazachstanas, nshepetyuk82@mail.ru

6 Vytauto Didžiojo universitetas, Švietimo akademija, T.Ševčenkos g. 31, LT-03111 Vilnius, Lietuva, sniegina.poteliuniene@vdu.lt

\section{Santrauka}

Straipsnyje pateikiami fizinio ugdymo programos, orientuotos $\mathfrak{i}$ individualų sveikatos stiprinimą, veiksmingumo rezultatai. Buvo tirtas I kurso studentų fizinis ir funkcinis parengtumas. Tyrime dalyvavo studentai vaikinai $(n=45)$, kurie neturejo sveikatos sutrikimų ir kurių vidutinis amžius $17,68 \pm 0,74$. Jie buvo suskirstyti ị kontrolinę $(n=23)$ ir eksperimentinę $(n=22)$ grupes. 
Kontrolinès grupès fizinio ugdymo pratybos buvo vykdomos pagal standartinę aukštosios mokyklos fizinio ugdymo programą. Eksperimentinès grupès studentai dalyvavo individualioje sveikatą stiprinančioje fizinio ugdymo programoje, kurios pagrindas aerobinès krypties bėgimo programa, parengta remiantis Cooper (1968): fizinis krūvis buvo individualizuojamas pagal skirtingą asmens fizinio parengtumo laipsnị. Abiejose grupėse pratybos truko po 110 minučių, jos buvo vykdomos du akademinius semestrus du kartus per savaitę. Pratybose daugiausia laiko buvo atliekami aerobiniai pratimai, kurių metu širdies susitraukimų dažnis buvo 100-160 tvinksnių per minutę. Be to, be teorinès dalies, pratybose buvo atliekami pratimai greitumui, koordinacijai, lankstumui. Studentų fizinis parengtumas buvo nustatytas atliekant motorinius testus (3000 m ir 100 m bėgimas; šuolis ị tolị iš vietos; prisitraukimai prie skersinio). Studentų funkciniam pajègumui nustatyti taikytas Martine-Kušelevskio testas. Duomenų analizė atlikta naudojant statistini paketą IBMSPSS Statistics 25. Tyrimo rezultatai patvirtina teigiamą individualios sveikatos gerinimo fizinio ugdymo programos poveikị studentų fiziniam ir funkciniam pasirengimui. Tai patvirtino statistiškai reikšmingai geresni studentų fizinio parengtumo rodikliai po pedagoginio eksperimento, taip pat ir geresnè jų širdies ir kraujagyslių sistemos reakcija ị standartinę apkrovą. Fizinio ugdymo programos, kuriose fizinis aktyvumas yra reguliuojamas atsižvelgiant ị kiekvieno studento funkcinị parengtumą naudojant širdies ritmo matavimo prietaisą, pagerina studentų fizinę būklę bei leidžia geriau ịvertinti studentų adaptaciją fiziniam krūviui. Šio tyrimo rezultatai gali padèti universiteto dèstytojams pagerinti studentų sveikatą taikant metodus ir priemones, padedančias studentams suprasti individualių pratimų ir fizinio krūvio svarbą siekiant sveikatos tikslų.

Esminiai žodžiai: studentai, adaptacija, fizinis ugdymas, funkcinis pajegumas. 